ZOOLOGIA 30 (3): 329-332, June, 2013

http://dx.doi.org/10.1590/S1984-46702013000300011

\title{
A new species of Imeri (Opiliones: Stygnidae: Heterostygninae) from the Brazilian Amazon
}

\author{
Amanda Coronato-Ribeiro',3, Ricardo Pinto-da-Rocha² \& Cristina Anne Rheims ${ }^{1}$ \\ ${ }^{1}$ Laboratório Especial de Coleções Zoológicas, Instituto Butantan. Avenida Vital Brasil 1500, 05503-900 São Paulo, SP, Brazil. \\ ${ }^{2}$ Departamento de Zoologia, Instituto de Biociências, Universidade de São Paulo. Caixa Postal 11461, 05422-970 São \\ Paulo, SP, Brazil. \\ ${ }^{3}$ Corresponding author. E-mail: amandacoronato@hotmail.com
}

\begin{abstract}
A new species of Stygnidae Simon, 1879, Imeri ajuba sp. nov., is described based on males and females from Coari, Amazonas, Brazil. The new species, differs from the only other species of the genus, Imeri lomanhungae Pinto-daRocha \& Tourinho, 2012, in having the following characteristics: three white marks on posterior margin of dorsal scutum, one white mark on free tergite I, three pairs of tubercles on area I, one pair of tubercles on area II, femur IV with ventromesal row of five tubercles, truncus of penis with six pairs of setae on lateral and ventral sides and ventral plate with two pairs of distal setae on dorsal portion.
\end{abstract}

KEY WORDS. Amazonas; harvestmen; Imeri ajuba sp. nov.; taxonomy, Brazil.

Stygnidae Simon, 1879 is a family of harvestmen that currently includes 97 species in 31 genera (Kuny 2003, PinToDA-Rocha \& Tourinho 2012). Species of this family are distributed north of the Capricorn Tropic in the Neotropics (PInTOda-Rocha 1997, Pinto-da-Rocha \& Tourinho 2012, VillarrealManzanilla \& Rodríguez 2004). In the past, species were known solely by their type specimens and thus morphological variations and population distributions were poorly known (Villarreal-Manzanilla \& Rodríguez 2004, Kury \& Pinto-da-Rocha 2002). Nevertheless, during the last fifteen years, taxonomical revisions and cladistic analyses have been carried out in Stygnidae, including descriptions of many new species and few genera, and new locality records.

The family is currently divided into three subfamilies: Stygninae Simon, 1879, Heterostygninae Roewer, 1913 and Nomoclastinae Roewer, 1943 (PINTO-DA-Rocha 1997). Heterostygninae is composed of nine genera and is characterized by claws III-IV opposite, pectinate, distitarsi III-IV depressed, pedipalpal coxa, femur and patella long, penis with ventral plate slender, distal setae shorter than width of ventral plate.

Within Heterostygninae, Imeri Pinto-da-Rocha \& Tourinho, 2012, hitherto includes only the type species, Imeri lomanhungae Pinto-da-Rocha \& Tourinho, 2012, from the highlands of Pico da Neblina, Amazonas, Brazil, close to Venezuelan border. The genus is characterized by the combination of the following characteristics: pedipalpus long and slender (including tibia and tarsus), white marks on posterior margin of dorsal scutum and very long spines on area III (PInTO-DA-Rocha \& Tourinho 2012).

In this paper, we describe a new species of Stygnidae, belonging to Imeri (PINTO-DA-Rocha \& TOURINHO 2012). The de- scription of this new species increases the geographical distribution of the genus and enables a more accurate diagnosis of it, including interspecific variation.

\section{MATERIAL AND METHODS}

The examined material is deposited in the following institutions (abbreviation and curator in parenthesis): Museu Paraense Emílio Goeldi, Belém (MPEG, A.B. Bonaldo), Museu de Zoologia da Universidade de São Paulo, São Paulo (MZSP, R. Pinto da Rocha), Instituto Butantan, São Paulo (IBSP, D.M. Barros Battesti). Measurements were taken with a micrometric ocular and are given in millimeters. Illustrations were made using a Leica MZ12 stereomicroscope with a camera lucida and microscope ZEISS Axioskop 2 Plus. Female's description includes only features that are different from male.

The length of the setae on the pedipalpal tarsus (without socket) is defined by Kury (1991) and PINTO-DA-Rocha (1997), "I" as a robust spine and " $\mathrm{i}$ " as a much smaller spine, that has less than half the length of the longest setae of the article.

\section{TAXONOMY}

\section{Imeri ajuba sp. nov.}

Figs 1-9

Type material. Male holotype from Base de Operações Geólogo Pedro de Moura $\left(04^{\circ} 48^{\prime} 23^{\prime \prime} S, 6^{\circ} 02^{\prime} 05^{\prime \prime W}\right)$, Porto Urucu, city of Coari, state of Amazonas, Brazil, 09.VII.2006, S.C. Dias, L.T. Miglio \& C.A.C. Santos Jr leg. (MPEG 01163). Paratypes: 3 females with the same data as holotype (MPEG 
01163); 1 female, ditto (IBSP 10609); 1 female, ditto (MZSP 52236); 3 females, same locality as holotype $\left(04^{\circ} 48^{\prime} 56^{\prime \prime} \mathrm{S}\right.$, 6501'53"W), VII.2006, C.A.C. Santos Jr leg., (MPEG 01124); 1

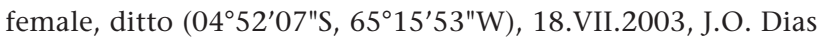
leg., (MPEG 01173); 1 male, ditto (IBSP 10608); 1 male, ditto (MZSP 52237).

Diagnosis. Imeri ajuba sp. nov. differs from I. lomanhungae by the presence of three white marks on posterior margin of dorsal scutum (only two on I. lomanhungae, see PINTO-DA-RochA $\&$ Tourinho 2012: 3, fig. 1A) and one white mark on free tergite I (absent on I. lomanhungae); presence of three tubercles on area I in male and one tubercle on area I in female (in $I$. lomanhungae one tubercle in male and female, see PINTO-DARocha \& Tourinho 2012: 3, fig. 1A) and one tubercle on area II (two tubercles on I. lomanhungae, see PINTO-DA-Rocha \& TourinHo, 2012: 3, fig. 1A); posterior margin of dorsal scutum smooth (four minute tubercles on I. lomanhungae, see PINTO-DA-Rocha \& Tourinho 2012: 3, fig. 1A) (Figs 1-2); femur IV with only one retrolateral row of small tubercles (Fig. 5) and ventromesal row of five tubercles (Fig. 6) (retrolateral, prolateral, dorsal rows of small tubercles and two ventral rows of tubercles on $I$. lomanhungae, see PINTO-DA-Rocha \& TouRinho 2012: 3, figs 1D and $1 \mathrm{E}$ ), presence of six pairs of long setae on lateral side of penis (five pairs on lateral side in I. lomanhungae, see PINTO-DARocha \& Tourinho 2012: 23, fig. 12B) (Fig. 8).

Male description (MPEG 01163). Measurements. See Table I. Dorsum (Figs 1-2). Anterior margin with two-three setiferous tubercles on each side. Lateral region more elevated at ozopore and with one tubercle on each side. Prosoma with nine central setiferous tubercles. Without tubercles between ocularium and groove I (Fig. 1). Lateral margin with one row of 14 tubercles from final region of coxa II to posterior margin (Fig. 2). Area I separated by median groove, with three setiferous tubercles on each side, II with one setiferous tubercle on each side, III with two very long and divergent spines distally pointed and directed backwards. Posterior margin smooth. Free tergite I with eight minute setiferous tubercles, II with six minute setiferous tubercles, III with nine minute setiferous tubercles (Fig. 1). Anal operculum with scattered setae. Venter. Coxa I with one row of four tubercles, II and III with row of six tubercles, IV irregularly tuberculate. Anal operculum with small tubercles and genital plate smooth. Chelicera. Bulla with four dorsal tubercles (Fig. 1). Segment II swollen, with one large tooth and eight small teeth, III with two large teeth and six small teeth. Pedipalpus (Figs 3-4). Right coxa with three dorsal tubercles and left coxa with four dorsal tubercles (Fig. 1), three ventral tubercles: two sub-basal and one sub-distal, trochanter with one dorsal and one ventral tubercle, femur smooth, patella smooth and swollen distally. Tibia: mesal IIIi (Fig. 3), ectal IIiIi (Fig. 4). Tarsus: mesal Iilii (Fig. 3), ectal iliIi (Fig. 4). Legs. Coxa I with two dorsal tubercles, II with one dorsal tubercle and one lateral tubercle fused to one of coxa III, IV with two-three dorsal tubercles. Trochanter I smooth, II with one retrolateral tubercle, III with two retrolateral tubercles and both trochanters with one proximal dorsal tubercle and two ventral tubercles, IV with three prolateral tubercles, four dorsal tubercles: one larger than the others and two retrolateral tubercles (Fig. 5). Femora I-II with one pointed dorsoapical tubercle, III with two pointed dorsodistal tubercles, IV with one retrolateral row of minute tubercles extended throughout proximal two thirds of femora, two dorsoapical tubercles with pointed apex (Fig. 5), one ventromesal distal tubercle and one ventroectal distal, one ventromesal distal row of five tubercles (Fig. 6). Patella III with two dorsoapical tubercles, IV with two dorsoapical tubercles, one ventral tubercle. Tibia IV with ventromesal row of six tubercles in the middle of the article (Fig. 6). Presence of scopula. Tarsal segmentation: 9(3), 15(3), 6, 7. Penis (Figs 7-9). Truncus with six pairs of long setae on lateral and ventral sides (Figs 8-9). Ventral plate with elongated base, distal margin U-shaped, two pairs of distal setae inserted on dorsal portion, one pair on lateral portion and two dorsal pairs of setae on basal region (Figs 7-8). Basal region of glans long and membranous. Dorsal process absent. Stylus narrow, long with apex slightly swollen (Fig. 8). Color. Pale yellow, with some irregular black marks on margin of dorsal scutum, next to ocularium, around the areas, on the spine of area III, free tergites and articulations. Three white marks on posterior margin of dorsal scutum and one white mark on free tergite I.

Female description (MPEG 01173): Measurements. See Table I. Dorsum. Anterior margin of dorsal scutum with two tubercles. Prosoma with five tubercles. Area I-II with one tubercle on each side, III with two long and divergent pointed spines. Lateral margin with row of 13 and 15 tubercles on each side. Free tergite I-II with six minute tubercles, III with 15 minute tubercles. Legs. Coxa I with two dorsal tubercles: one tubercle directed towards pedipalp coxa and another tubercle directed towards coxa II, III with two lateral ventral rows of four tubercles. Femur III with one dorsoapical tubercle, IV with one retrolateral row of minute tubercles on the proximal half. Patella III smooth, IV with one retrolateral distal tubercle. Pedipalpus. Coxa with two ventral tubercles, tibia mesal IIIIi, ectal IIIIi. Tarsus mesal IiIIi, ectal iIiIi. Color. Dark yellow, re-

Table I. Imeri ajuba sp. nov., measurements in millimeters of the male holotype and female paratype.

\begin{tabular}{lcc}
\hline & Male holotype & Female paratype \\
\hline Dorsal scutum length & 2.5 & 2.6 \\
Dorsal scutum width & 2.1 & 2.1 \\
Prosoma length & 1.0 & 1.1 \\
Prosoma width & 1.9 & 1.9 \\
Interocular distance & 1.2 & 1.2 \\
Chelicera & 2.3 & 1.2 \\
Pedipalpus length & 5.3 & 4.2 \\
Pedipalpal femur & 2.7 & 2.6 \\
Legs I, II, III, IV & $8.8,18.8,11.2,15.3$ & $6.2,19.9,11.8,16.4$ \\
Leg IV femur & 4.8 & 5.0 \\
\hline
\end{tabular}



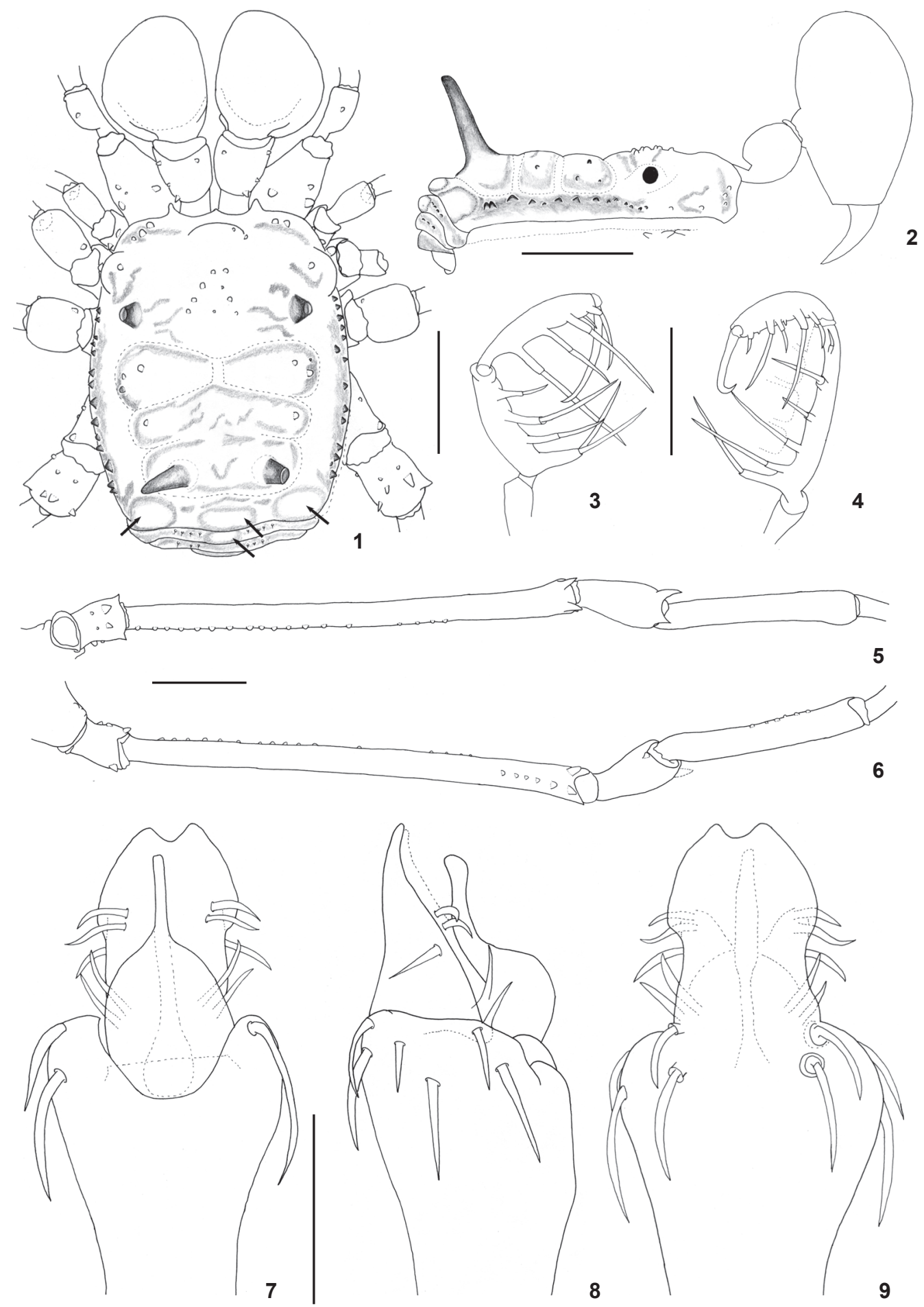

Figures 1-9. Imeri ajuba sp. nov., male (MPEG 01163): (1-2) habitus: (1) dorsal view, the arrows indicate the white marks, the grey stripes are patches of reticulate black around the areas, prosoma, lateral margin and spines; (2) lateral view; (3-4) right pedipalpus: (3) mesal view, (4) ectal view; (5-6) trochanter-tibia of the right leg IV: (5) dorsal view, (6) ventral view; (7-9) penis: (7) dorsal view; (8) lateral view; (9) ventral view. Scale bar: $1 \mathrm{~mm}$. 
ticulate black around the areas, prosoma, lateral margin and spines. Legs, pedipalps and chelicera pale yellow. Articulations dark. Three white marks on the posterior margin of dorsal scutum and one white mark on free tergite I. Tarsal segmentation: 9 (3), 12 (3), 5, 6.

Distribution: This species is known only from the type locality in Coari, state of Amazonas, extending the distribution of the genus to the central region of the state, closer to the capital, Manaus, and in lowlands (about 40 m.a.s.l.).

Etymology: The specific name, "ajuba", means yellow in the Tupi Native Brazilian Indian language and refers to the beautiful color that predominates in the body of this species.

Remarks. In the original diagnosis of Imeri, the number of setae on apical region of truncus is five. However, figure 12A-C (Pinto-DA-Rocha \& Tourinho 2012) shows five setae on one side and six on the other. The generic diagnosis should thus be emended to five to six pairs of setae on apical truncus. The body shape with lateral margins of dorsal scutum convex is similar to most Heterostygninae and probably is the primitive condition within this subfamily. The penis has features that we believe are putative synapomorphies with species of Yapacana Pinto-da-Rocha, 1997, Eutimesius Roewer, 1913, and Inoxius Pinto-da-Rocha, 1997. These characters are: base of the ventral plate long, dorsal setae of ventral plate more centrally placed, and narrow cleft on apical region of ventral plate. In addition, species of Imeri share with species of Yapacana and Stygnoplus Simon, 1879 the absence of the dorsal process of the penis. Nevetheless, Stygnoplus and Stenostygnellus Roewer, 1913 are sister-groups based on features not shared with Imeri spp., such as anterior sockets of pedipalpal tibia with bifid apex, membranous part of the glans penis restricted to basal region and narrow and short base of ventral plate of penis (see PINTODA-Rocha 1997). The position of the genus within the phylog- eny of the group is difficult to infer without conducting a cladistic analysis.

\section{ACKNOWLEDGMENTS}

This study was supported by Programa de Aprimoramento Profissional - FUNDAP (ACR), FAPESP (CAR, 2011/20211-0 and RPR, 11/18694-3) and CNPq (RPR). We are grateful to Osvaldo Villarreal-Manzanilla, for revision and suggestions on an earlier version of this manuscript.

\section{LITERATURE CITED}

KuRY, A.B. 1991. Notes on Mitobatinae IV: Ischnotherus tenebrosus new genus and new species of Brazilian harvestman. Mitteilungen aus dem Zoologisches Museum in Berlin 67 (2): 351-359.

KuRY, A.B. \& R. PINTO-DA-Rocha. 2002. Opiliones, p. 345-362. In: J. ADIS (Ed.). Amazonian Arachnida and Myriapoda. Sofia, Pensoft Publishers, 590p.

KurY, A.B. 2003. Annotated catalogue of the Laniatores of the New World (Arachnida, Opiliones). Revista Ibérica de Aracnología 1: 1-337.

PINTO-DA-Rocha, R. 1997. Systematic review of the neotropical family Stygnidae (Opiliones, Laniatores, Gonyleptoidea). Arquivos de Zoologia 33 (4): 163-342.

Pinto-DA-Rocha, R. \& A.L. Tourinho. 2012. Two new genera, ten new species and new records of Amazonian Stygnidae Simon, 1879 (Opiliones: Laniatores). Zootaxa 3340: 1-28.

Villarreal-Manzanilla, O. \& C.J. Rodríguez. 2004. Descripción de una nueva especie y dos nuevos registros del género Stygnoplus (Opiliones, Stygnidae) para Venezuela. Revista Ibérica de Aracnologia 10: 179-184.

Submitted: 30.VIII.2012; Accepted: 21.IX.2012.

Editorial responsibility: Antonio D. Brescovit 